\title{
BEYOND COMPASSIONATE AID: Precarious Bureaucrats and Dutiful Asylum Seekers in Italy
}

\author{
DANIELA GIUDICI \\ University of Trento \\ (D) https: / / orcid.org/0000-0002-5769-2728
}

So here I am, a victim of a violent system, exactly like those who are in front of me [i.e., the asylum seekers] and unload on me their frustration. And me, who I am actually a human being, I respond to another human being with my own anger, the anger of someone who sees her own aspirations and hopes getting wasted in a ruinous project, with job contracts that do not allow you to plan your life and forge your future, precarious projects for precarious workers, and sometimes a sense of exhaustion and bitterness stands above everything. . . . I don't have the right to holiday or sick leave, because I have a short-term contract. But this, to those who are in front of us, we cannot explain it. Hence, they often see us as distant, bored . . . and we cannot establish a connection with the human being that lies beyond the "guest." (Galieni 2015)

This is an extract of a public letter, written in 2015 by an anonymous worker employed in a refugee reception center in Rome. ${ }^{1}$ Since I began ethnographic fieldwork in the Italian asylum system in 2010, I have been puzzled by the ubiquitous presence of a background critique to the asylum system's functioning and organization. Recurrent frustration was not only expressed by asylum seekers, who were 
suffering on a daily basis from the inadequacies of a reception system that has had a hard time meeting even their most basic needs. Indeed, reception workers also expressed deep discontent, ${ }^{2}$ often complaining both about their insecure working conditions and about the asylum system's multiple dysfunctions. Overall, a strong sense of uncertainty and vulnerability seemed to pervade the institutional encounters I witnessed.

On the one hand, in contemporary Italy, asylum seekers are oppressed by an extremely fuzzy and intricate bureaucratic machine, which leaves them suspended in an unsettled and marginal position while waiting for a response to their applications (Beneduce 2015; Fontanari 2018). Taking a closer look, protracted marginality also often permeates the lives of those who have obtained legal status, due to the overlapping effects of inadequate inclusion policies and multiple discriminatory practices (Pinelli 2013; MSF 2016). This scenario certainly holds true beyond Italy, although some of its features appear exacerbated in this specific national context. Indeed, the contemporary scenario of an immigration "crisis" affecting the global North tends to shape a transnational asylum system implicitly aimed at protracting asylum seekers' existential incertitude and, therefore, their potential "removability" from the national territory (Peutz 2006; de Vries and Guild 2019).

On the other hand, Italian reception workers are increasingly compelled to accept uncertain and exploitative working conditions. Until quite recently in Italy, the majority of social workers found employment with the public sector and therefore enjoyed its relative stability and protection. Yet in the early 2000s the architecture of the Italian welfare system was broadly reshaped, both vertically, by delegating responsibilities and funding to regional and municipal levels, and horizontally, by devolving services to the "nonprofit third sector" in accordance with the Catholic-derived principle of subsidiarity (Marchesi 2020, 6; see also Rose 1996). ${ }^{3}$ The "thirdness" of this sector stands in relation to the first and second domains of market and state; it encompasses a multiplicity of nongovernmental subjects, such as cooperatives, NGOs, and volunteer organizations (Ranci 2001). Although many of the current neoliberal trends that affect Italian society are often presented in public discourse as a "necessary sacrifice" required by the contemporary economic recession, their roots are much more entrenched (see also Powers and Rakopoulos 2019). Whereas the third sector in Italy elicits fantasies of distance from both state and market logics, it is in fact entangled with and dependent on both (Muehlebach 2012). The fast withdrawal of the Italian state from the provision of public services, encouraged also by the fiscal demands of European monetary unification, has allowed a new kind of labor force to be employed in so- 
cial service provision: nowadays a growing number of social workers are hired by third sector actors, with poorly protected and underpaid contracts. In fact, a third sector worker costs on average 40 percent less than a public servant employed in the same position. As in the passage quoted above, social workers are experiencing the transition to unregulated working conditions with a range of emotions, from anxiety to frustration and anger. This complex mix of material and affective unrest often finds articulation through the term precario (precarious), which, as Noelle J. Molé $(2010,38)$ has noted, in contemporary Italy "is an ontological claim that exceeds economic typology and becomes a way of identifying subjects' classed position and psychic interiority." These frustrating working conditions seem to have profound consequences both on a personal level (impossibility of forging one's future) and on the dynamic of aid that they end up providing to asylum seekers (impossibility of establishing a connection with "the human being that lies behind the guest").

Although the liminal condition of asylum seekers has been well documented in rich ethnographies (Khosravi 2010; Cabot 2014; Fontanari 2018), less known is the precarious state of uncertainty faced by street-level bureaucrats (Lipsky 2010) burdened with the task of concretely enacting the progressive withdrawal of the state from its obligations in terms of asylum rights. In line with studies that urge us to go beyond the citizen/non-citizen divide and examine "refugees' and citizens' partially shared continuum of precarity" (Cabot 2019, 5-7; see also Anderson 2013), I explore shifting paradigms of refugee management in Italy in the light of broader processes of workplace regime transformation. Drawing on ethnographic research with asylum-related bureaucratic workers in Bologna, Italy, I address some of the paradoxical and violent effects of welfare decline both on reception workers' labor conditions and on the dynamic of aid that they end up providing to asylum seekers.

My argument has two main theoretical points. First, I argue that recent developments of asylum management in Italy suggest a transition toward post-compassionate forms of aid, hinged more on the production of dutiful subjects ready to repay the "hospitality" offered by the state than on the moral imperative to rescue suffering bodies or lives. Recent anthropological scholarship on asylum in Europe (and beyond) has focused on the politics of legitimation of the unstable category of refugee, revealing the specific configurations of "deserving human life" embedded in aid institutions and practices (see, for example, Fassin 2005; Rozakou 2012; Cabot 2013). This body of literature has revealed the exclusionary-albeit often unintended - consequences of compassionate humanitarianism, understood as a 
moral and political project hinged on the suffering victim (Ticktin 2014, 275). In the context of European immigration management, the tension between a politics of piety and policies of control (Fassin 2005) translated into the privileged status assigned to the suffering body in aid distribution and legalization procedures. ${ }^{4}$ It is not by chance that in Italy, recognition as a "victim" — either of human trafficking or of persecution as defined by the 1951 Refugee Convention - is virtually the only means of achieving a residency permit for migrants already present in the country (see also Giordano 2008).

Yet early in my fieldwork, I started realizing that human vulnerability was not the only cornerstone around which everyday aid practices were built and organized. Asylum seekers were not simply conceived as "suffering bodies" (Fassin and d'Halluin 2005), "helpless sufferers" (Huschke 2014), or "disabled citizens" —as, in other words, inhabiting a limited humanity produced on the ground by a politics of compassion (Ticktin 2006, 35). Indeed, in the context of welfare decline and increasingly "anxious politics" surrounding migration (de Koning and Modest 2017), new configurations of "deservingness" seemed to be taking shape (Holmes and Castañeda 2016). In the bureaucratic settings I encountered, reception workers increasingly encouraged asylum seekers to display a dutiful, willing, and, quite surprisingly, "caring" attitude in order to show their eligibility for some, albeit partial, social and legal rights. In fact, some forms of recognition seemed granted to subjects ready to conform to stereotypical representations of a European citizen (e.g., by performing "socially useful" and unpaid volunteer work) and, simultaneously, to occupy the most subordinate positions in Italian society. On the one hand, the push to engage in voluntary work echoed the recent institutionalization of volunteerism as a laboratory for the production of new "responsible citizens" in the context of social care privatization (Muehlebach 2012; Rozakou 2016). On the other hand, the presence of asylum seekers in the national territory, and related access to its "community of value" (Anderson 2013), remained conditional and highly uncertain (Marchetti 2020). Hence, as I will detail, processes of socioeconomic transformation and transformed cultural expectations around supposedly deserving guests come together to elicit novel forms of subaltern inclusion, ones not fully encompassed by the tropes of humanitarian compassion.

I make my second but related point by suggesting that to move beyond a single focus on either a refugee crisis or an economic crisis may help us better contextualize and trace emerging political subjectivities and possibilities. The shifts in the politics of legitimation of Others described in this article were materially implemented by an array of social workers who, as in the opening quote, experienced 
a sharp deterioration in their own labor rights and living conditions. These two sides of the story, far from being unrelated, have much to tell about current reconfigurations of forms of (non)citizenship in southern Europe and beyond. Indeed, financial recession and austerity policies have highlighted how not only migrants' but also citizens' rights face profound reconfiguration, "such that citizens and their noncitizen counterparts are not always clearly distinguishable by a set dividing line but instead hover along a gradation of rights and rightlessness" (Muehlebach 2012, 26; see also Cabot 2019). In fact, both asylum workers' precarization and asylum seekers' involvement in voluntary work evoke highly moralized forms of (non)citizenship_-based more on sacrifices and duties than on the actual enjoyment of rights - emerging in the context of the dismantling of the welfare state (Hyatt 2001; Muehlebach 2011). Yet populist discourses and policies often have the effect of shifting images of victimhood from the body of the migrant to the body of the nation, thus further separating marginal segments of society, migrants or not.

In what follows, I first reconstruct the deep-seated narrative of emergency and scarcity that characterizes Italian immigration management, from well before the beginning of the 2015 so-called European refugee crisis. Then, I examine the recent institutional endorsement of refugee volunteerism against the backdrop of paternalizing forms of social support and moralized forms of (non)citizenship. The ethnographic core of the article focuses on everyday encounters between reception workers and asylum seekers in Bologna, a city once considered a model for welfare services. By tracing the effects of an affectively charged scenario centered around feelings of vulnerability and uncertainty, I show how precarious bureaucrats, frustrated by insecure and demanding jobs, find themselves engaged in ambiguous processes of aid distribution that are embedded in new normative ideals of the "deserving guest." In the final part of the article, I sketch elements of the recent xenophobic turns of the Italian sociopolitical landscape, turns that have involved a further exacerbation of exclusionary narratives and practices, as well as meaningful forms of dissent. These restrictive changes have deeply affected not only asylum seekers but also reception workers, who-alongside human rights activists, solidarity movements, and NGOs - have come to represent the internal enemies of nativist propaganda (Zamponi 2017; Tazzioli and Walters 2019). Reception workers' feelings of marginalization were only exacerbated by drastic budget cuts in 2018, which led to the closure of several migrant reception centers and to the layoff of many reception workers. Under such conditions, modes of agency and sites of contestation may emerge even from within what have been traditionally described as sites of antipolitics, namely, humanitarian aid institutions and practices 
(see also Cabot 2013, 453). Indeed, reception workers' precarious positioning and dissent hold the potential for exposing the inherent contradictions of state-based narratives, thereby bringing to the fore alternative discourses on the causes and responsibilities of both the migrant crisis and the austerity crisis.

This article draws on ethnographic data collected between 2010 and 2012, as well as on ongoing research since 2018, in the field of asylum in Italy. I collected much of the material for this article at one particular reception office, instituted by Bologna's local administration, which provided bureaucratic assistance and support to asylum seekers and refugees. Its coordinators were public servants, hired on a long-term basis by the local administration. Conversely, reception workers engaged in the daily assistance to asylum seekers and refugees were employed by social cooperatives, often on a short-term basis.

\section{“CRISIS” AND SHIFTING PATTERNS OF VICTIMHOOD}

Italy is a major threshold of Europe for numbers of people coming from the Middle East and Africa. ${ }^{5}$ After a period of relative slowdown in the flow of maritime arrivals, since 2010 Italy's southern shores have experienced a renewed increase in migrant boat landings, reaching a peak with the so-called 2015 refugee crisis (Fondazione Ismu 2016). Yet people fleeing economic and political violence were meeting the systemic injustices of European migration policies long before Syrian displacement on an unprecedented scale brought the refugee issue to the attention of the general public (Fernando and Giordano 2016; Cabot 2019). As a matter of fact, in Italy, even before the mediatized beginning of the European refugee crisis, a significant number of people both with a pending asylum application and with a protected status usually spent their days looking for charitable food or shelter, sleeping in vacant buildings or train stations, and sometimes finding exploitative and temporary work in the informal economy (MSF 2016). The Italian asylum reception system is very complex, as it involves a number of state and nongovernmental actors, strong regional variations, and recurrent changes of functions (D’Angelo 2018, 5-7). The country's reception capacity has always proven inadequate to the needs of asylum seekers. In the words of a reception worker I encountered in 2011: "We all know that reception measures theoretically would be a right of asylum seekers. However, in practice, it is not like that. It's hard to say, but we can't save them all. . . . In the end it's not a right, it's an option.” In this context, Italy, much like other southern European countries, has been alternately criticized by EU central authorities for being either an insufficient guardian of European borders or an inadequate host to newcomers (Rozakou 2012, 563). 
A deep-seated narrative of emergency and scarcity, as well as a generalized moral panic surrounding the idea of migration itself, seem to stand out as the well-established trademarks of Italian migration management (Mai 2002; Campesi 2011). The logic of treating the entrenched phenomenon of migration as a permanent emergency allows for the suspension of the regular rule of law by activating exceptional, and often discriminatory, instruments of intervention. At the same time, the depiction of migration as a "human flood," a "human tsunami," or even a "biblical exodus," which has a long-standing tradition in Italian political discourse, displaces a sense of vulnerability from the body of the migrant/refugee to the body of the nation (Garelli and Tazzioli 2013; see also Hage 2016). This was exemplified when, in April 2011, the Italian government nominated Civil Protection as the managing unit of the "refugee crisis" resulting from the Arab Spring. The Italian Civil Protection's traditional competence covers natural catastrophes (such as forest fires, floods, volcano eruptions, and earthquakes), and it has no expertise on refugee issues. This choice spelled a political vision that cast refugees as a natural catastrophe for the receiving country: "It was not first and foremost the body of the refugee that bears vulnerability ... ; it was also (and eminently) the land of the receiving country that became somehow vulnerable because of the refugee influx" (Garelli and Tazzioli 2013, 1008). In addition, an emergency rationale has proven a useful tool for an opaque management of the so-called migration crisis. Indeed, although mainstream representations describe an objective and indisputable lack of resources, in the last few years the Italian state has invested millions of euros in the asylum reception system. These funds have proven irresistible to criminal organizations, corrupted politicians, and unscrupulous administrators, making the reception system an extraordinary engine for the accumulation of profit from the tragedies of one of the most underprivileged sectors of society. ${ }^{6}$ Nonetheless, when a populist narrative of invasion, predation, and scarcity dominates Italian political discourses and media representations, asylum seekers are increasingly perceived as undesirable guests and an unsustainable burden for a collapsing welfare state.

\section{DUTIFUL (NON)CITIZENS}

In May 2015, the Italian interior minister, Angelino Alfano (center-right), proposed in parliament that asylum seekers should "work for free" (lavorare gratis) for the municipalities hosting them while their applications are being processed. In a press conference, he commented: "Instead of keeping them doing nothing, at least they should make them work." These comments instigated heated debates in parliament and in the public arena, with the leader of the right-wing North- 
ern League, Matteo Salvini, provocatively accusing Alfano of having shifted from scafista (smuggler) to schiavista (slaver). And yet, asylum seekers had already been involved in "volunteering projects" at least since 2011, particularly in the center and north of Italy. In early 2017, the issue gained public attention again when the newly elected interior minister, Marco Minniti (center-left), unveiled a plan "to cover part of the expenses of hosting the migrants and help improve the souring relationships between refugees and locals" (Momigliano 2017). In recent years the cost of asylum seekers has become a thorny issue in Italian political life, as conservative politicians and media outlets depict refugees as freeloaders who divert resources from poor Italian families. Here, again, a narrative of victimhood is shifted from refugees to "Italians," as the responsibility for suffering is displaced "from historical, political and economic policies supported by powerful actors in Europe and the United States to the displaced people themselves" (Holmes and Castañeda 2016, 2). Such stories resonate in a country severely hit by financial recession, where the number of citizens living below the poverty line has risen from 3 percent to 8 percent in the past decade (Caritas Italiana 2016). In an early formulation, the Minniti plan envisaged the possibility of making community service a mandatory requirement for asylum seekers. After the "unpaid labor requirement" attracted harsh criticism from legal scholars and refugee advocates for being unconstitutional, asylum seekers' unwaged labor was reframed as volunteer and "socially useful community work" (lavori socialmente utili), receiving widespread approval.

The figure of the volunteer has recently emerged as a central category in Italian public life. Italy was the first country to treat volunteerism with a distinct body of law, and no other country in Europe relies as extensively on volunteer labor as Italy_about one-quarter of all nonprofit organizations rely exclusively on volunteers (Ranci 2001; see also Muehlebach 2012, 10). Andrea Muehlebach (2012), reflecting on the rise of a new regime of voluntary labor in Italy, remarks that highly moralized forms of citizenship are emerging in the context of welfare and care privatization. She has developed the concept of "ethical citizenship" to indicate how in contemporary Italy, as the state shifts the burden of providing social services onto a citizenry conceptualized as active and dutiful, "citizens imagine themselves as bound together by moral and affective rather than social and political ties, and primarily through duties rather than rights" (Muehlebach 2012, 43). Asylum seekers' involvement in volunteer work clearly evokes some of this scenario's elements, and more generally of the "mantra of active citizenship," which anthropologists working in many parts of the world have described as one of the 
main features of neoliberal governmentality (Hyatt 2001; Fleischer 2011; Rozakou 2016). In recent years, refugee volunteer work has generally been praised in Italian public and media discourses as a useful remedy against the protracted inactivity that asylum seekers are otherwise forced to experience during their asylum claim assessment. Most important, by performing socially useful volunteer work, asylum seekers are expected to refurbish their negative image among local populations. As a service coordinator commented during a personal conversation in 2018: "Volunteering sends a good message to Italians, who don't appreciate seeing migrants doing nothing all day."

It is noteworthy, however, that the services asylum seekers are often called to perform are limited to essential, low-level community services (such as sweeping the streets, shoveling snow, or maintaining public parks), which local administrations burdened by financial cuts are struggling to provide. While hinting at novel forms of asylum management in times of austerity, these social projects also play on distinctive racial and postcolonial imaginaries that insist on a substantial difference between supposed insiders and outsiders and, at the same time, on the paternalizing mission of rendering migrant bodies as deserving of modern social support (see, among others, Silverstein 2005; De Genova 2016). In this respect, it should not go unnoticed that Italian institutional attempts to manage migrants today are conditioned by unresolved questions about Italy's past and ambiguous negotiations between nationalization, internal migration from south to north, and colonialism (Schneider 1998; Mai 2002; Giordano 2008). As several anthropologists have noted, an enduring denial of racism and intolerance-from northern prejudices toward southern Italians to a widespread disregard of "new immigrants" - constitutes a structural trait of Italian society (e.g., Cole 1997; Holmes 2000). Taking a closer look, an increased racialization of the labor force has proven crucial in managing the contemporary narrative of austerity by strengthening competition within the working class and, at the same time, producing cheap and disposable migrant workers (Oliveri 2018). The massive promotion of volunteering jobs, which traditionally entailed remuneration, also threatens a delicate balance in the already fragile labor market, thereby worsening the conflict between failed citizens (Italians or long-term migrants) and noncitizens (asylum seekers). Against this backdrop, a destabilizing and affectively charged atmosphere of uncertainty and lack of future possibilities permeates asylum-related institutional encounters, during which reception workers mainly engage in taming unrealistic aspirations and demands from their interlocutors. 


\section{THIS IS ITALY}

One gray morning in the winter of 2011 I was assisting Elena, ${ }^{7}$ a reception worker in her thirties, in her daily duties at the office of the International Protection Service. Elena had a master's degree in international relations and had started working for the service two years earlier, as an unpaid intern. After the internship, the managing social cooperative hired her on a six-month contract. Outside her office there was, as usual, a long queue of people waiting to be received. It was the turn of a newly arrived asylum seeker, a young woman. She walked into the office with an attitude of dismay, looking lost. Elena started asking the woman, who introduced herself as Rose, for some basic information about herself and her situation. Rose could not speak Italian, and so the conversation was held in French. Rose had landed three days earlier at the airport in Rome, coming from the Democratic Republic of Congo. She then had taken a train with some other asylum seekers, who had advised her to get off in Bologna. Since then, she had been sleeping in the train station. Due to the constant overcrowding of asylum reception centers, Elena had no accommodation to offer to Rose. Yet she explained to Rose that she stood a good chance in the coming months of finding a place in a reception center dedicated to women, as she was alone, without family or support. Then, Elena took out a brochure about facilities for homeless people in the city. Until a place in a housing structure opened up, Rose's only option was to sleep in the city's public dorm and to eat at one of the soup kitchens run by Catholic organizations. Here is how Elena explained to Rose what her first steps should be in the search for charitable food or shelter:

First of all, you have to go to the public shelter ... here [pointing at a map]. You'll have to go there very early in the morning, around 6 or 7 a.m., and you will probably have to queue at least for four or five hours to get a bed. You should know that this is a place where everybody can go to sleep . . . everybody who doesn't have a home. I mean, there you'll also find people that stink. ... Then you'll have to go to this place ...

Rose looked at Elena with a puzzled face and interrupted her: "Well, why should I go there? I am an asylum seeker. I have the right to get accommodation." Elena looked at me with a tired expression and then replied: "I know that, but this is not how things work here. This is the only thing I can offer you for the moment. But, as I told you, if you are a bit patient, as a woman, you'll probably get a place in a reception center." Rose insisted that this was Europe and that she knew her rights, 
becoming increasingly agitated. Elena sighed, visibly tired, and replied: "Listen, I am just doing my job. I know that it's not easy for you. . . . But this is how things work here . . . this is Italy, it's not Europe."

Italy, in contrast to other southern European countries including Greece, was once perceived as a core country in European geopolitical and moral geographies (cf. Cabot 2014). In this sense, Elena's comments are emblematic of an unprecedented and pervasive sense of collective failure. It is even more striking given that Bologna, as I will elaborate, is considered a model city for welfare services, at both national and international levels. Nevertheless, I encountered this kind of situation repeatedly during my fieldwork research. Reception workers often described the Italian asylum system as a field of governance saturated with multiple "crises" (job crisis, welfare state crisis, migration crisis, and so on), essentially marked by an endemic scarcity of resources, as well as by a lack of direction or strategy. They tended to perceive and present the Italian state as a peripheral area of the "European territory of rights," substantially unable to fulfill its moral and legal responsibilities toward its citizens, as well as toward protection seekers (see also Cabot 2019). On the other hand, many asylum seekers expressed outrage at being repeatedly confronted with this scenario of humiliation and destitution. Although mostly aware of the multiple flaws in the Italian reception system, in struggling to articulate their claims through the vocabulary of human rights, they revealed the far-stretched contradictions of the European project as a universalist umbrella of rights and democracy.

\section{PRECARIOUS BUREAUCRATS}

The city of Bologna represents a paradigmatic example of the massive outsourcing of state social services to the third sector. Traditionally considered "Italy's showcase city of the Left," as well as a center of excellence for welfare services (Però 2005), Bologna is the principal city of the Emilia-Romagna region. In the 1970s and early 1980s the Emilia-Romagna region attracted international attention for a model of development that realized positive economic performances and, simultaneously, fostered social cohesion. In recent years, however, the "Emilian model" has progressively deteriorated, with the effect of disclosing many of its structural ambiguities (Kertzer 1980; Heywood 2015). Under the generalized pressure of establishing a slimmer, cheaper, and more cost-effective welfare state, the regional administration is currently undertaking a substantial transformation from a public model to a semi-private one. Traditionally ruled by the left-wing Partito Democratico (Democratic Party), the local government's current policies 
seem to "fit quite well with the new 'post-socialist' course of the Left and its accommodating posture vis-à-vis the neoliberal transformation of society, which includes the rolling back of the state, cuts in public spending, the subordination of political powers to economic ones with the consequent exclusion of the economy from the sphere of political intervention" (Però 2005, 852).

Provision of the majority of social services, immigration services among them, is currently subcontracted to the ASP (Azienda Servizi alla Persona, literally Company for the Services to the Person), a modern, refashioned version of well-established Catholic charity institutions. ${ }^{8}$ The "ASP system" represents a structurally hybrid form of governance, as these institutions are rooted in the non-profit sector of Catholic inspiration and, at the same time, are strictly dependent on local government decisions. This hybrid institution subcontracts the hiring of its streetlevel workers to social cooperatives active in the social sector. One of these ASP subcontractors was the local manager of the office where I conducted part of my ethnographic fieldwork, and where Elena worked, which here I call International Protection Service (IPS). The reception workers employed at IPS were in large part women between twenty-five and forty-five years old. They hailed from diverse educational backgrounds (with degrees ranging from international relations to social sciences or cultural mediation), and their work tasks were various and somewhat blurred. While mainly tasked with providing assistance in the asylum claim application, they also engaged in a number of more or less related duties, whether offering guidance in the quest for shelter or health assistance or managing access to asylum reception measures. In the everyday life of the reception office, the new social services (dis)organization was at the center of a number of discussions and critiques. In the first instance, the deregulation of the welfare labor regime seemed to reduce people's ability to perform everyday tasks by introducing a permanent anxiety about the temporary nature of the workers' presence. For example, Anna, a reception worker in her thirties employed on a short-term basis, spoke of the strict time constraints imposed by the new administration as follows:

It's not possible to work in these conditions. . . . The people we are assisting wait on average ten to twelve months before knowing the decision about their international protection claim. On the other hand, you're always uncertain about your future and you are not given the possibility to assist the clients properly. In the end, we are never sure about whether we'll be here next month. It's true that in recent years they have been renewing contracts, 
but almost every month you basically don't know what to expect. . . . Basically, it's a mafia. ${ }^{9}$

The new organization gave rise to discourses organized around sentiments of resentment and vulnerability. Reception workers tended to perceive the new environment as predatory, confusing, and abusive. They experienced the constant uncertainty about the future as a sort of violent blackmail-illustrated by the comment, "basically, it's a mafia" — that leaves the worker feeling stuck, deprived of the possibility of understanding and controlling the mechanism's logics. A series of anxieties and preoccupations were directed toward the system itself, depicted as an unknowable, irrational, and thoughtless governing structure. Here is how a worker addressed his colleagues during an internal meeting: "Either we start building a group identity or we are stuck, and they are going to crush us. The system has no direction. They keep on sucking our resources, and we don't even know it. They keep on doing things, and we don't even know it. And there is no direction or strategy." The ASP itself emerged as a major source of complaints, often presented as an institution ruled by people with no experience in immigration services and therefore completely unaware of the kind of problems they encountered daily. In this context, older workers tended to express nostalgic feelings for the previous welfare organization, in which they were directly subordinate to the public administration. Indeed, the ASP's intermediary role was often presented not only as responsible for their increased precariousness but also as the source of many organizational malfunctions. Here is how Rita, a senior caseworker, articulated the transformed nature of the relationship with the police department since the reorganization of the immigration services:

Rita: The shift of the immigration services to the ASP was a huge mistake. Since we have this new organization, it's simply a mess. For example, now we are no longer considered as part of the municipality, and the police department is simply not considering us anymore. This morning I was there with an asylum seeker and, as usual, there was a huge line. And they left us waiting for hours outside their offices, in the cold. I'm telling you, it's humiliating for me to go there and to be treated like that.

Me: Was it different before?

Rita: Of course! It was completely different. We were considered representatives of the local authorities. We had a stable position. But now, they just ignore us, they don't respect our work. 
Rita's comments offer a powerful critique of the open-ended and contradictory nature of the state form, whose boundaries are continuously made and unmade in everyday social life (Gupta 1995; Thelen, Vetters, and von Benda-Beckmann 2014). At the same time, in the bureaucratic settings I encountered, it was common to hear people refer nostalgically to a previous organization of social services - whether or not they directly experienced it themselves — when resources and possibilities were more available (see also Muehlebach and Shoshan 2012).

It is beyond doubt that asylum seekers in contemporary Italy endure a degree of existential and material precarity far from comparable to that experienced by the reception workers I encountered during my fieldwork. On closer examination, the latter's uneasiness was not merely elicited by the insecurity of their own labor conditions but also by the awareness of working within a system substantially unable to fulfill its moral and legal responsibilities toward protection seekers, leaving most of them to wrestle with extremely harsh living conditions. Yet the accelerated deregulation of the welfare state, of which their own employment formed an integral part, seemed to play an important role in the rise of collective feelings of oppression and vulnerability, as well as in the deployment of novel forms of asylum management, not solely encompassed by the tropes of humanitarian compassion.

\section{DESERVING GUESTS AND PRODUCTIVE BODIES}

About six months after our first encounter, I again met Rose in the rooms of the IPS. She looked better, entering Elena's office with a big smile. Rose was now being hosted in a center for women asylum seekers, and her asylum application was still pending. Elena and Rose discussed bureaucratic matters for a while. After Rose left the office, Elena commented to me: "Did you see how she looks calmer now? She is a very determined and active woman. She is attending two Italian classes, she knows the city very well, and she's really keen on working. Everybody is very satisfied with her." Elena then met with the social worker in charge of assisting Rose in her housing facility. She wanted to suggest that Rose volunteer in an association engaged in the assistance of elderly people: "I think that this might be a very good idea for her. Did you hear what they said during the last meeting with asylum claim evaluators? At the end it is very important what they are doing here, perhaps even more than what they did there. . . . Well, it's understandable . . . because if someone claims to flee his country for some rights and then does not care at all about others. ..."

In the bureaucratic settings I encountered, asylum seekers were taught not only to care for themselves and thus avoid weighing on a shrinking welfare state 
(Ong 2003), but also to care about others. As the fragments of conversation above illustrate, asylum seekers' involvement in volunteer work was often perceived as a precondition to more favorable treatment in the quest for social and legal rights. This implicit and informal requirement recalls an array of legislative frameworks, scholarly works, and state policies that in recent years have contributed to the construction of volunteer work as an ideal of civic participation and Europeanness (Rozakou 2016). ${ }^{10}$ Yet since international conventions define asylum as a universal right, those implicit assumptions clearly upend the very meaning of a right as a legal entitlement that does not entail reciprocity or repayment, whether symbolic or material. In this sense, the widespread promotion of refugee volunteerism seems to embody not so much an ideal of civic engagement and "integration", but rather an ideology that subordinates (partial) rights to goodwill.

The push to volunteerism is embedded in the repeated insistence, which I heard frequently during my fieldwork, that some asylum seekers are, as a matter of personal character, particularly "willing” (volenteroso), "active” (attivo), and "cooperative" (collaborativo), which usually led to more favorable treatment. Tellingly, these deserving personality traits reflect a shifting paradigm in the politics of hospitality displayed in times of austerity and waning welfare state protections. The moral primacy granted to vulnerability and victimhood, described as one of the main features of compassionate politics in various European countries (Fassin and d'Halluin 2005; Ticktin 2006; Cabot 2013), had-and, to some extent, still has - certain resonance in the Italian context (see Giordano 2008; Giudici 2014; Beneduce 2015). However, the pressure on asylum seekers to become involved in volunteering programs, which grew exponentially after 2015, hints at a different logic of (de)legitimation. A model of engaged noncitizenry actively contributing to the social life of the hosting community does not seem to rest on a classical understanding of compassionate humanitarianism, ready to grant legitimacy to vulnerable victims in the name of their suffering and unproductive body (Fassin 2005). ${ }^{11}$ On the contrary, it is the productive body of the migrant that is invoked to attract an aura of legitimacy around his/her otherwise undesirable presence.

Yet not all migrants felt ready to play the role of the dutiful asylum seeker and to engage in unpaid, voluntary work. As Ahmed, a young asylum seeker from Somalia, told me: "They asked me to go and clean the parks. Well, I can do that, but I want to get paid. I mean, I am here, I just want a job, I need money to live. . . This story of volunteering is really nonsense." As opposed to the "ethical citizen" who "desires and seeks pleasure in unwaged labour," as described by Muehlebach (2011, 75), Ahmed's comments shed light on how asylum seekers in fact experi- 
enced refugee volunteerism as deeply coercive. Yet such non-compliant attitudes were often met with suspicion and mistrust. Indeed, since many reception workers began their own careers as unpaid interns, the refusal to engage in volunteerism often confirmed a widespread conviction that asylum seekers lacked a "sense of reality." In a context where reception workers themselves experienced financial difficulties and political marginalization, everyday institutional interactions were fraught with complex and contradictory emotions, ranging from frustration and exasperation to understanding and, at times, empathy (see also Casati 2018). To be sure, reception workers' aid practices tended to enact shifting moral economies of what distinguishes between "good" and "bad" (non)citizens (Ong 2003). In doing so, workers often tried to help asylum seekers gain better access to scarce opportunities. Yet as the situation for both migrants and workers increasingly deteriorated, critical stances and open conflicts became more visible and widespread.

\section{BETWEEN RECEPTION AND STRUGGLE}

Italy found itself generally unprepared for the constant increase in the number of migrants arriving between 2014 and 2016 as part of the so-called European refugee crisis. The drastic intensification of arrivals prompted an expansion of the overall capacity of its undersized reception system, which grew from about 22,000 facilities in 2013 to more than 190,000 facilities by 2017, mainly via the creation of a parallel and chaotic system of so-called extraordinary reception centers (CAS — centri di accoglienza straordinaria). It should not go unnoticed that this capacity expansion also represented expanded opportunities for (precarious) employment for many young people, many of them humanities graduates with a background in anthropology (cf. Altin and Sanò 2017). Yet as the emergency regime became, once again, a structural feature of migrant management (Campesi 2018), the already fragile allegiance of asylum workers to state institutions began to crack, laying bare underlying tensions (Giudici 2020). In March 2016, reception workers announced their first general strike. As the presentation flyer stated: "Reception workers' exploitation, the emergency regime, and the idea that social work is equivalent to volunteering all have devastating consequences on the services offered within refugees' centers and, mainly, on migrants' pathways to inclusion and autonomy. This is why the struggles for workers' and migrants' rights should not be distinct." ${ }^{2}$

Meanwhile, the greater visibility of migrants in many municipalities, combined with the misperception (fueled by media and political discourses) that reception costs siphoned away funding from other policy measures, contributed to the 
construction of an undisputable "migrant crisis" (Marchetti 2020, 241). In the face of mounting hostility toward migration, in 2018 a new Immigration and Security Decree drastically restricted services and facilities available to asylum seekers and refugees in the country. Among its major consequences, the decree further marginalized migrants by portraying asylum seekers as illegal aliens, and it abolished the residency permit for humanitarian protection, underscoring the fading political emphasis on compassionate humanitarianism. Until 2018, a humanitarian permit was one of the residence permits granted in the legislative framework of international protection, one that accounted for 30 percent of the Italian asylum system beneficiaries. Its abolition resulted in a predictable increase in "irregular migration” and social marginality (IDOS 2019).

The drastic budget cuts led to the closure of several reception centers and to the layoff of many reception workers. ${ }^{13}$ Against this backdrop, critical voices coming from the inside, as well as public protests involving both reception workers and asylum seekers, grew ever louder in many Italian cities (Baratta 2019; La Repubblica 2019). By bringing together the plight of asylum workers and refugees' claims, these recent political struggles work to shape an alternative discourse on Others, one based not on the intrinsic asymmetries of compassion (see also Arendt 2006), but rather on shared mechanisms of oppression. The disruptive potential of these forms of dissent proves even more meaningful as asylum workers find themselves in the position of epitomizing "the left hand of the state" in the implementation of controversial state policies (Spire 2007; Cabot 2014; Kalir 2019). Moreover, these mobilizations hint at transversal alliances and collective actions that can actually emerge through the folds of what have been described as sites of "antipolitics," namely, humanitarian aid systems and practices (Ferguson 1994; Ticktin 2006). Nick Gill (2009), while reflecting on third sector workers employed in the asylum system in the United Kingdom, reminds us that these intermediate actors, despite being pushed toward discretionary decision-making through an array of state-managed conditionings, also inhabit pivotal sites of contestation and potential sites of resistance. In Gill's $(2009,9)$ words, state power "is eminently resistible, precisely because it rests upon the allegiance of critically reflexive actors to the idea of the state itself." Precarious reception workers, because of their ambivalent relationship with the same state institutions they represent, hold the potential of playing a crucial role in the development of such struggles. 


\section{CONCLUSIONS: After Compassion}

In Italy, crisis-thinking and its consequences, by shifting images of vulnerability from the body of the migrant to the body of the nation, (re)opened the way to policies and attitudes dominated by securitarian preoccupations and xenophobic sentiments, while simultaneously concealing well-rooted processes of welfare state retrenchment that concern migrant and native persons alike. In the context of widening disparities and emergent populisms, the moral imperative to rescue suffering bodies and lives appears, maybe for the first time, under attack. ${ }^{14}$ It is not by chance that in recent years we have witnessed a growing criminalization of citizens, human rights activists, and NGOs that intervene in support of migrants and refugees, both inside European territory and during search-and-rescue operations in the Mediterranean Sea. The criminalization of maritime rescue and solidarity practices is clearly linked to the rise of far-right parties and their increasing power to institutionalize xeno-racist biases (see Fekete 2009). In Italy, the leader of the far-right Lega Party, Matteo Salvini, has made targeting those who "facilitate illegal migration" a hallmark of his reign as interior minister. The policing of grassroots humanitarian assistance is widespread across Europe and indicative of shifting paradigms of government that, as I have tried to show in this article, are inexorably moving beyond the tropes of a politics of compassion.

When the fundamental importance attributed to the suffering body - and to human life — as the last terrain of a common humanity seems called into question, novel forms of subaltern inclusion take shape. To be sure, the emerging figure of the volunteering refugee is shot through with deep ambivalences and contradictions. While formally promoting asylum seekers' increased civic participation in the hosting society, the aggressive promotion of those activities also crystallizes the erosion of asylum rights for the "unwanted," as well as the imposition of normative subjectivities through inherently paternalistic workfare schemes. Since 2016, the pressure on asylum seekers to engage in volunteering programs has grown exponentially in Italy_and since 2018, migrants' access to asylum procedure and protections have seen significant constraint. As a reception worker noted to me in August 2020, "migrants are still expected to behave well and demonstrate their respect for Italian institutions, but they have lost their hope of being somehow rewarded for their good behavior." In fact, the "dutiful asylum seeker," deeply embedded in the neoliberal production of subjectivities, hints at strategies of governance that, once again, rest on and reproduce both structural inequalities and racialized classifications of human value (see Thomas and Clarke 2013). 
Nonetheless, as new compromises and forms of exploitation take shape, unexpected political opportunities may yet arise. Interestingly, such opportunities might emerge not only from outside but also from "within the organizational terrain we call the state” (Mitchell 1991, 93, cited in Mountz 2003, 639). In contemporary Italy, responsibility for the withdrawal of the Italian state from its obligations to asylum seekers is assumed by street-level bureaucrats, who find themselves in the position of administrating increasingly inadequate reception measures while experiencing the progressive waning of their own social rights. The precarious reception workers investigated in this article are concretely involved in implementing aid practices that may end up reinforcing frameworks of exclusion. Yet they also stand out as critically reflexive actors whose detachment from the same institutions they represent could open a path to multiple forms of dissent. That they are not public servants but, rather, precarious third sector workers certainly plays a role in the emergence of their critical stance. Indeed, an ethnographic analysis of state-based forms of humanitarian support sheds light on the relational nature of the state, understood not as a monolithic actor but rather as a social construction whose boundaries are continuously made, unmade, and contested in everyday social life (Thelen, Vetters, and von Benda-Beckmann 2014). Furthermore, it reminds us that even in sites of anti-politics, such as humanitarian aid systems, forms of agency and unexpected political opportunities may arise. In this sense, the fading centrality of a compassionate ethos, while strictly connected to repressive policies informed by a blunt disregard for human life, might open the door to an alternative discourse on Others, one based neither on pity nor charity but instead on a re-politicization of the notion of solidarity (Siapera 2019). Engaging solidarity as a contentious political terrain relates to the emergence - in southern Europe and beyond — of a variegated landscape of anti-austerity socialities that challenge migration border controls (Tazzioli and Walters, 2019) as well as official versions of volunteerism and humanitarian charity (Rakopoulos 2014; Rozakou 2016; Theodossopoulos 2020). As both the refugee crisis and the austerity crisis are, in fact, symptoms of an underlying deep structural crisis of capitalism, we should pay more attention to the political spaces in which transversal alliances between migrants and citizens might take shape.

\section{ABSTRACT}

In this article, I track shifting paradigms of refugee management in Italy in times of austerity and welfare state restructuring. Drawing on an ethnographic analysis of asylum-related bureaucratic work in Bologna, the essay explores paradoxical and 
violent effects of welfare decline both on reception workers' labor conditions and on the dynamic of aid that they end up providing to asylum seekers. On the one hand, recent developments in asylum management in Italy suggest a transition to post-compassionate forms of aid, hinged more on the making of dutiful subjects ready to repay the "hospitality" offered by the state than on the moral imperative to rescue suffering bodies and lives. On the other hand, reception workers' precarious positioning and unrest hold the potential for exposing the inherent contradictions of state-based narratives, thereby shaping alternative discourses on the causes and responsibilities of both refugee and economic "crises." [asylum; neoliberal governance; asylum workers; citizenship; precarity; compassion; Italy]

\begin{abstract}
Questo articolo ricostruisce l'emergere di nuovi paradigmi di gestione dei rifugiati in Italia, in tempi di austerità e ristrutturazione dei sistemi di welfare. Prendendo spunto dall'analisi etnografica di un ufficio di supporto per l'asilo a Bologna, l'articolo esplora effetti violenti e paradossali dello smantellamento del welfare pubblico, sia sulle condizioni di lavoro degli operatori dell'accoglienza, che sulle dinamiche di aiuto a richiedenti asilo che essi finiscono col contribuire a produrre. Le recenti trasformazioni nella gestione dell'asilo in Italia suggeriscono uno slittamento verso forme di aiuto post-compassionevoli, incentrate più sulla costruzione di soggetti attivamente impegnati nel ricompensare "l'ospitalità" offerta dallo stato, che sull'imperativo morale di salvare corpi e vite sofferenti. Al tempo stesso, la precarietà e il dissenso dei lavoratori dell'accoglienza sono potenzialmente in grado di illuminare alcune delle contraddizioni intrinseche alle narrazioni statali, elaborando così discorsi alternativi sulle cause e responsabilità della "crisi", sia migratoria che economica. [asilo; governance neoliberale; lavoratori dell'accoglienza; cittadinanza; precarietà; compassione; Italia]
\end{abstract}

\title{
NOTES
}

Acknowledgments I would like to express my sincere thanks to all my field interlocutors who shared with me their thoughts and time. I am particularly grateful to Katerina Rozakou for her generous and inspiring feedback on this article. The argument in this essay also benefited from feedback received within the research group Anthropology of Global Inequalities at the Freie Universität Berlin. In particular, I would like to thank Katharina Schramm for her detailed and insightful comments. Special thanks go to Kyra Grieco, Stefania Japo, and Anita Sunda, who have commented on drafts and ideas at various stages. My gratitude also goes to the anonymous reviewers for their productive and detailed comments, as well as to the Cultural Anthropology editorial team and, in particular, to Heather Paxson, for her invaluable guidance throughout the revision process. Research for this article was supported by a Doctoral Fellowship of the Italian Ministry of Education, University and Research and a Postdoctoral Fellowship within the MIUR-FARE HOASI Project at the University of Trento.

1. My translation.

2. In Italy, not all the workers employed in the asylum reception system hold a degree in social work, nor are they specialized humanitarian professionals. In Italian they are usually named operatori dell'accoglienza, "reception workers." 
3. The separation of the church from the Italian state has been a central theme since unification, when the state could not afford to alienate the Catholic Church because of its wealth and charitable apparatus. As a matter of fact, the church's resources still play a pivotal role in the implementation of Italian social policies (Quine 2002; see also Giordano 2008).

4. Whereas compassionate humanitarianism finds its roots in deep-seated charitable paradigms of Catholic inspiration, the upsurge of moral sentiments and, in particular, of compassion in political action is linked to the growing global importance since the early 1990s of NGOs, such as the French-born Médecins Sans Frontières (MSF) (Redfield 2005). In Italy a residency permit for "humanitarian reasons" was instituted in 1998 as a "flexible visa" for specific conditions of vulnerability, such as pathologies declared unable to receive proper treatment in the country of origin (see also Ticktin 2006).

5. Until the early 1990s Italy was not a country of settlement for refugees. The issue of refugees erupted into the Italian public imagination in 1991, with the massive arrival of Albanians fleeing their country after the fall of the communist regime and, subsequently, of refugees from ex-Yugoslavia. From the end of the 1990s onward the refugee flows toward Italy changed radically. Italy's southern shores became the destination of migrants from different African countries, crossing the Mediterranean through Libya and Egypt. While the so-called 2010 Arab Spring caused a sudden spike of asylum applications in Italy, the highest increase came with the 2015 European refugee crisis. According to UNHCR, the number of asylum claims received by Italy in 2015 (about 67,000) was four times the level of that seen in 2012. Eritrea and Somalia, former Italian colonies, together with Nigeria were the first countries of origin of asylum seekers in 2015. After 2016, due to the implementation of Salvini's closed-ports policy, combined with EU efforts to limit arrivals and outsource responsibility to countries outside of the European Union, asylum applications sharply decreased.

6. In December 2014, Italian prosecutors unveiled a close collaboration of criminal groups and corrupt politicians in the awarding of the contracts for the management of several asylum seeker reception centers. The opportunity for illegal profit was sensationally articulated by the man at the center of the so-called Mafia Capitale corruption scandal in Rome, Salvatore Buzzi, who was recorded telling an associate that drugs were "less profitable" than the business of housing asylum seekers. On the Mafia and migrant centers in Italy, see, among others, Gaia Pianigiani (2017).

7. Names and some details have been modified to protect research participants' identities.

8. Those charitable institutions, in many cases quite ancient, are managers of a considerable patrimony of assets and properties. For instance, immigration services were subcontracted to an ASP (Poveri e Vergognosi, literally, "Poor and Ashamed"), founded in 1495, whose real estate holdings in the territory of Bologna are estimated to cover 55,000 square meters.

9. In everyday Italian, the term mafia can be used in a broad sense, going far beyond the established meaning of "organized crime." It can refer, as in this case, to a group of people that uses its power illicitly to achieve personal interests.

10. Katerina Rozakou (2016) describes the "crafting of the volunteer" in the beginning of the twenty-first century in Greece as a laboratory for the production of new European and Greek citizens. Her insightful analysis has a certain resonance in the Italian context, yet there are important differences. Whereas the push to volunteerism in Greece takes place through a top-down vision of modernizing an "underdeveloped" Greek civil society, in Italy (or at least in northern Italy) the sentiment of volunteerism, while also state-mediated, seems to be embodied by a larger public in search of social recognition through affective - and unremunerated - labor (Muehlebach 2011).

11. In her ethnography of asylum claims evaluations made by judges at the Bologna tribunal, Barbara Sorgoni (2019) also refers to the fading centrality of the suffering body. She situates her analysis within a wider shift from a "culture of suspicion" that emerged in the 1990s and a more recent "culture of rejection," produced by European policies striving to deter the arrival of migrants in the European continent. Sorgoni argues that, at a time 
when rejection (rather than suspicion) becomes the political imperative, adjudication procedures rely less on the body — sick, traumatized, wounded - and more on mere oral testimony, which can eventually allow for speedier denials.

12. Public statement available at https://www.sialcobas.it/2016/02/1-marzo-lappello-dei-lavoratori-dellaccoglienza-di-roma/ (accessed May 25, 2020).

13. Under the new asylum regime, an estimated 18,000 reception workers have lost or are about to lose their jobs (Marchetti 2020, 248).

14. In October 2013, just after two migrant shipwrecks in Lampedusa caused more than four hundred deaths, the Mare Nostrum Operation was launched by the Italian government as a military and humanitarian operation aimed both "at safeguarding human life at sea and bringing to justice migrant smugglers." It was the last search-and-rescue operation carried out by the Italian government, which ended its activities in October 2014 after rescuing some 150,000 migrants. See https://web.archive.org/web/20150416233445/ https://www.iom.int/cms/en/sites/iom/home/news-and-views/press-briefing-notes/ pbn-2014b/pbn-listing/iom-applauds-italys-life-saving.html.

\section{REFERENCES}

Altin, Roberta, and Giuliana Sanò

2017 "Richiedenti asilo e sapere antropologico." Antropologia Pubblica 3, no. 1: 8-34. http://dx.doi.org/10.1473/anpub.v3i1.94.

Anderson, Bridget

2013 Us and Them? The Dangerous Politics of Immigration Control. Oxford: Oxford University Press.

Arendt, Hannah

2006 On Revolution. London: Penguin Classics.

Baratta, Lidia

2019 "Migliaia di licenziati e 80mila irregolari in più: Il bilancio di un anno del decreto sicurezza di Salvini." Linkiesta, November 8. https://www.linkiesta.it/2019/11/ un-anno-decreto-sicurezza-accoglienza/.

Beneduce, Roberto

2015 "The Moral Economy of Lying: Subjectcraft, Narrative Capital, and Uncertainty in the Politics of Asylum." Medical Anthropology 34, no. 6: 551-71. https://doi.org/ 10.1080/01459740.2015.1074576.

Cabot, Heath

2013 "The Social Aesthetics of Eligibility: NGO Aid and Indeterminacy in the Greek Asylum Process.” American Ethnologist 40, no. 3: 452-66. https://doi.org/10.1111/ amet.12032.

2014 On the Doorstep of Europe: Asylum and Citizenship in Greece. Philadelphia: University of Pennsylvania Press.

2019 "The European Refugee Crisis and Humanitarian Citizenship in Greece." Ethnos 84, no. 5: 747-71. https://doi.org/10.1080/00141844.2018.1529693.

Campesi, Giuseppe

2011 "The Arab Spring and the Crisis of the European Border Regime: Manufacturing Emergency in the Lampedusa Crisis." Working Paper, EUI RSCAS, 2011/59, Mediterranean Programme Series, Robert Schuman Centre for Advanced Studies, European University Institute. http://hdl.handle.net/1814/19375.

2018 "Between Containment, Confinement and Dispersal: The Evolution of the Italian Reception System before and after the 'Refugee Crisis."' Journal of Modern Italian Studies 23, no. 4: 490-506. https://doi.org/10.1080/1354571x.2018.1501995.

Caritas Italiana

2016 Vasi Comunicanti: Rapporto sulla povertà e l'esclusione sociale in Italia. Teramo: Edizioni Palumbi. 
Casati, Noemi

2018 "How Cities Shape Refugee Centres: 'Deservingness' and 'Good Aid' in a Sicilian Town.” Journal of Ethnic and Migration Studies 44, no. 5: 792-808. https://doi.org/ 10.1080/1369183X.2017.1354689.

Cole, Jeffrey

1997 The New Racism in Europe: A Sicilian Ethnography. Cambridge: Cambridge University Press.

D’Angelo, Alessio

2018 "Italy: The 'Illegality Factory'? Theory and Practice of Refugees' Reception in Sicily." Journal of Ethnic and Migration Studies 45, no. 12: 1-14. https://doi.org/10.1 080/1369183X.2018.1468361.

De Genova, Nicholas

2016 "The European Question. Migration, Race, and Postcoloniality in Europe." Social Text 34, no. 3: 75-102. https://doi.org/10.1215/01642472-3607588.

de Koning, Anouk, and Wayne Modest

2017 "Anxious Politics in Postcolonial Europe." American Anthropologist 119, no. 3: 52426. https://doi.org/10.1111/aman.12916.

de Vries, Leonie Ansems, and Elspeth Guild

2019 "Seeking Refuge in Europe: Spaces of Transit and the Violence of Migration Management." Journal of Ethnic and Migration Studies 45, no. 12: 2156-66. https:// doi.org/10.1080/1369183X.2018.1468308.

Fassin, Didier

2005 "Compassion and Repression: The Moral Economy of Immigration Policies in France.” Cultural Anthropology 20, no. 3: 362-87. https://doi.org/10.1525/ can.2005.20.3.362.

Fassin, Didier, and Estelle d'Halluin

2005 "The Truth from the Body: Medical Certificates as Ultimate Evidence for Asylum Seekers." American Anthropologist 107, no. 4: 597-608. https://doi.org/10.1525/ aa.2005.107.4.597.

Fekete, Liz

2009 "Europe: Crimes of Solidarity." Race and Class 50, no. 4: 83-97. https://doi. Ferguson, James org/10.1177\%2F0306396809103000.

1994 The Anti-Politics Machine: "Development," Depoliticization, and Bureaucratic Power in Lesotho. Minneapolis: University of Minnesota Press.

Fernando, Mayanthi, and Cristiana Giordano, eds.

2016 "Refugees and the Crisis of Europe.” Hot Spots series, Fieldsights, June 28. https:// culanth.org/fieldsights/series/refugees-and-the-crisis-of-europe.

Fleischer, Friederike

2011 "Technology of Self, Technology of Power: Volunteering as Encounter in Guangzhou, China." Ethnos 76, no. 3: 300-25. https://doi.org/10.1080/00141844. 2011.565126.

Fondazione Ismu

2016 Ventunesimo Rapporto sulle migrazioni 2015. Milano: FrancoAngeli.

Fontanari, Elena

2018 Lives in Transit: An Ethnographic Study of Refugees' Subjectivity across European Borders.

Galieni, Stefano Abingdon: Routledge.

2015 "Sono un'operatrice dello Sprar." Corriere delle Migrazioni, April 12. http://www. corrieredellemigrazioni.it/2015/04/12/lettera-operatrice-dellaccoglienza/.

Garelli, Glenda, and Martina Tazzioli

2013 "Arab Springs Making Space: Territoriality and Moral Geographies for Asylum Seekers in Italy." Environment and Planning D: Society and Space 31, no. 6: 1004-21. https://doi.org/10.1068\%2Fd15812. 
Gill, Nick

2009 "Presentational State Power: Temporal and Spatial Influences over Asylum Sector Decision Makers." Transactions of the Institute of British Geographers 34, no. 2: 215Giordano, Cristiana 33. https://doi.org/10.1111/j.1475-5661.2009.00337.x.

2008 "Practices of Translation and the Making of Migrant Subjectivities in Contemporary Italy." American Ethnologist 35, no. 4: 588-606. https://doi.org/10.1111/j.15481425.2008.00100.x.

Giudici, Daniela

2014 "La vita materiale dei mondi burocratici: Certificati medici, procedure di asilo e ricerca etnografica." Mondi Migranti 3: 109-25. https://doi.org/10.3280/mm2014003007.

2020 "The List: On Discretion and Refusal in the Italian Asylum System." European Journal of Social Work 23, no. 3: 437-48.

Gupta, Akhil

1995 "Blurred Boundaries: The Discourse of Corruption, the Culture of Politics, and the Imagined State." American Ethnologist 22, no. 2: 375-402. https://doi. org/10.1525/ae.1995.22.2.02a00090.

Hage, Ghassan

2016 “État de Siège: A Dying Domesticating Colonialism?" American Ethnologist 43, no. 1: 38-49. https://doi.org/10.1111/amet.12261.

Heywood, Paolo

2015 “Equivocal Locations: Being 'Red' in 'Red Bologna." Journal of the Royal Anthropological Institute 21, no. 4: 855-71. https://doi.org/10.1111/1467-9655. 12291.

Holmes, Douglas R.

2000 Integral Europe: Fast-Capitalism, Multiculturalism, Neofascism. Princeton, N.J.: Princeton University Press.

Holmes, Seth M., and Heide Castañeda

2016 "Representing the 'European Refugee Crisis' in Germany and Beyond: Deservingness and Difference, Life and Death." American Ethnologist 43, no. 1: 12-24. https://doi.org/10.1111/amet.12259.

Huschke, Susann

2014 "Performing Deservingness: Humanitarian Health Care Provision for Migrants in Germany." Social Science and Medicine 120: 352-59. https://doi.org/10.1016/j. socscimed.2014.04.046.

Hyatt, Susan Brin

2001 "From Citizen to Volunteer: Neoliberal Governance and the Erasure of Poverty." In The New Poverty Studies: The Ethnography of Power, Politics, and Impoverished People in the United States, edited by Judith Goode and Jeff Maskovsky, 201-35. New York: New York University Press.

IDOS

2019 Dossier statistico immigrazione 2018. Roma: IDOS Edizioni.

Kalir, Barak

2019 "Repressive Compassion: Deportation Caseworkers Furnishing an Emotional Comfort Zone in Encounters with Illegalized Migrants.” PoLAR 42, no. 1: 68-84.

Kertzer, David I. https://doi.org/10.1111/plar.12281.

1980 Comrades and Christians: Religion and Political Struggle in Communist Italy. Cambridge:

Khosravi, Shahram Cambridge University Press.

2010 The "Illegal" Traveller: An Auto-Ethnography of Borders. London: Palgrave.

La Repubblica

2019 “Migranti Bologna: Cresce la protesta per la chiusura dell'hub di Via Mattei." La Repubblica, June 10. https://bologna.repubblica.it/cronaca/2019/06/10/news/ 
migranti_bologna_cresce_la_protesta_per_la_chiusura_dell_hub_di_via_ mattei-228447157/.

Lipsky, Michael

2010 Street-Level Bureaucracy: Dilemmas of the Individuals in Public Services. New York: Russell Sage Foundation. Originally published in 1980.

Mai, Nicola

2002 "Myths and Moral Panics: Italian Identity and the Media Representation of Albanian Immigration." In The Politics of Recognising Difference: Multiculturalism Marchesi, Milena Italian Style, edited by R. D. Grillo and Jeff Pratt, 77-95. Aldershot: Ashgate.

2020 “The Intimate Public of Relational Welfare in Milan.” Ethnography. Published ahead of print, February 23, 2020. https://doi.org/10.1177\%2F1466138119897094.

Marchetti, Chiara

2020 “(Un)Deserving Refugees: Contested Access to the 'Community of Value' in Italy." In Europe and the Refugee Response: A Crisis of Values?, edited by Elżbieta M.

Mitchell, Timothy Goździak, Izabella Main, and Brigitte Suter, 236-52. London: Routledge.

1991 "The Limits of the State: Beyond Statist Approaches and Their Critics." American Political Science Review 85, no. 1: 77-96. https://doi.org/10.2307/1962879.

Molé, Noelle J.

2010 "Precarious Subjects: Anticipating Neoliberalism in Northern Italy's Workplace." American Anthropologist 112, no. 1: 38-53. https://doi.org/10.1111/j.1548-1433. 2009.01195.x.

Momigliano, Anna

2017 "Italy May Require Asylum Seekers to Do Community Service." Washington Post, January 25. https://www.washingtonpost.com/news/worldviews/wp/2017/01/ 25/italy-may-require-asylum-seekers-to-do-community-service/.

Mountz, Alison

2003 "Human Smuggling, the Transnational Imaginary, and Everyday Geographies of the Nation-State." Antipode 35, no. 3: 622-44. https://doi.org/10.1111/14678330.00342.

MSF (Medici senza Frontiere)

2016 Fuori Campo: Richiedenti asilo e rifugiati in Italia: Insediamenti informali e marginalità sociale. Medici senza Frontiere: Rome.

Muehlebach, Andrea

2011 "On Affective Labor in Post-Fordist Italy." Cultural Anthropology 26, no. 1: 59-82. https://doi.org/10.1111/j.1548-1360.2010.01080.x.

2012 The Moral Neoliberal: Welfare and Citizenship in Italy. Chicago: University of Chicago Press.

Muehlebach, Andrea, and Nitzan Shoshan

2012 "Introduction." In "Post-Fordist Affect," edited by Andrea Muehleach and Nitzan Shoshan. Special issue, Anthropological Quarterly 85, no. 2: 317-43. https://doi.

Oliveri, Federico org/10.1353/anq.2012.0030.

2018 "Racialization and Counter-racialization in Times of Crisis: Taking Migrant Struggles in Italy as a Critical Standpoint on Race." Ethnic and Racial Studies 41, no. 10: 1855-73. https://doi.org/10.1080/01419870.2018.1391404.

Ong, Aiwha

2003 Buddha Is Hiding: Refugees, Citizenship, the New America. Berkeley: University of California Press.

Però, Davide

2005 "Left-Wing Politics, Civil Society and Immigration in Italy: The Case of Bologna." Ethnic and Racial Studies 28, no. 5: 832-58. https://doi.org/10. 1080/01419870500158877. 
Peutz, Nathalie

2006 “Embarking on an Anthropology of Removal.” Current Anthropology 47, no. 2: 217Pianigiani, Gaia 41. https://doi.org/10.1086/498949.

2017 “Mafia in Italy Siphons Huge Sums from Migrant Centers.” New York Times, July 17. https://www.nytimes.com/2017/07/17/world/europe/italy-migrants-mafia-

Pinelli, Barbara, ed. edoardo-scordio.html.

2013 “Migrazioni e asilo politico." Special issue, Antropologia Annuario 15. https://www. ledijournals.com/ojs/index.php/antropologia/issue/view/20.

Powers, Theodore, and Theodoros Rakopoulos

2019 “The Anthropology of Austerity: An Introduction.” Focaal 83: 1-12. https://doi. org/10.3167/fcl.2019.830101.

Quine, Maria Sophia

2002 Italy's Social Revolution: Charity and Welfare from Liberalism to Fascism. Houndsmills, Basingstoke, Hampshire: Palgrave.

Rakopoulos, Theodoros

2014 "Resonance of Solidarity: Meanings of a Local Concept in Anti-austerity Greece." Journal of Modern Greek Studies 32, no. 2: 313-37. https://doi.org/10.1353/mgs. 2014.0040 .

Ranci, Costanzo

2001 “Democracy at Work: Social Participation and the 'Third Sector' in Italy.” Daedalus 130, no. 3: 73-84. https://www.amacad.org/publication/democracy-work-socialparticipation-and-third-sector-italy.

Redfield, Peter

2005 "Doctors, Borders, and Life in Crisis." Cultural Anthropology 20, no. 3: 328-61. https://doi.org/10.1525/can.2005.20.3.328.

Rose, Nikolas

1996 "The Death of the Social? Re-figuring the Territory of Government." Economy and Rozakou, Katerina Society 25, no. 3: 327-56. https://doi.org/10.1080/03085149600000018.

2012 "The Biopolitics of Hospitality in Greece: Humanitarianism and the Management of Refugees." American Ethnologist 39, no. 3: 562-77. https://doi.org/10.1111/ j.1548-1425.2012.01381.x.

2016 "Crafting the Volunteer: Voluntary Association and the Reformation of Sociality." Journal of Modern Greek Studies 34, no. 1: 79-102. https://doi.org/10.1353/mgs. 2016.0014.

Schneider, Jane, ed.

1998 Italy's “Southern Question”: Orientalism in One Country. Oxford: Berg.

Siapera, Eugenia

2019 "Refugee Solidarity in Europe: Shifting the Discourse." European Journal of Cultural Studies 22, no. 2: 245-66. https://doi.org/10.1177\%2F1367549418823068.

Silverstein, Paul A.

2005 "Immigrant Racialization and the New Savage Slot: Race, Migration, and Immigration in the New Europe." Annual Review of Anthropology 34: 363-84.

Sorgoni, Barbara https://doi.org/10.1146/annurev.anthro.34.081804.120338.

2019 "The Location of Truth: Bodies and Voices in the Italian Asylum Procedure." PoLAR 42, no. 1: 161-76. https://doi.org/10.1111/plar.12282.

Spire, Alexis

2007 "Ĺasile au guichet: La dépolitisation du droit des étrangers par le travail bureaucratique." Actes de la recherche en sciences sociales 4, no. 169: 4-21. https:// www.cairn.info/revue-actes-de-la-recherche-en-sciences-sociales-2007-4page-4.htm\#. 
Tazzioli, Martina, and William Walters

2019 “Migration, Solidarity and the Limits of Europe." Global Discourse 9, no. 1: 175-90. https://doi.org/10.1332/204378918X15453934506030.

Thelen, Tatjana, Larissa Vetters, and Keebet von Benda-Beckmann

2014 "Introduction to Stategraphy: Toward a Relational Anthropology of the State." Social Analysis 58, no. 3: 1-19. https://doi.org/10.3167/sa.2014.580302.

Theodossopoulos, Dimitrios

2020 "Solidarity Dilemmas in Times of Austerity: Auto-ethnographic Interventions." Cultural Anthropology 35, no. 1: 134-66. https://doi.org/10.14506/ca35.1.10.

Thomas, Deborah A., and M. Kamari Clarke

2013 "Globalization and Race: Structures of Inequality, New Sovereignties, and Citizenship in a Neoliberal Era." Annual Review of Anthropology 42: 305-25. https://

Ticktin, Miriam doi.org/10.1146/annurev-anthro-092412-155515.

2006 "Where Ethics and Politics Meet: The Violence of Humanitarianism in France." American Ethnologist 33, no. 1: 33-49. https://doi.org/10.1525/ae.2006.33.1.33.

2014 “Transnational Humanitarianism.” Annual Review of Anthropology 43: 273-89. https://doi.org/10.1146/annurev-anthro-102313-030403.

Zamponi, Lorenzo

2017 "Practices of Solidarity: Direct Social Action, Politicisation and Refugee Solidarity Activism in Italy." Mondi Migranti 3: 99-117. https://doi.org/10.3280/mm2017003005 . 